\title{
Study of Anti-Inflammatory Activity in vitro of four Essential Oils from Gabon
}

\author{
Mathouet $\mathrm{H}^{1^{*}}$, Sima Obiang $\mathrm{C}^{2,3}$, Mbogho Abogo $\mathrm{J}^{2}$, Bourobou Bourobou $\mathrm{HP}^{4}$, Ondo $\mathrm{JP}^{2,3}$
}

${ }^{1}$ Laboratoire de Recherche en Phytochimie, Institut de pharmacopée et de Médecine Traditionnelles B.P. 1156, Libreville, Gabon

${ }^{2}$ Laboratoire de Recherche en Biochimie (LAREBIO), Université des Sciences et Techniques de Masuku B.P. 943, Franceville, Gabon

${ }^{3}$ Laboratoires de Substances Naturelles et de Synthèses Organométalliques (LASNSOM), Université des Sciences et Techniques de Masuku B.P. 943,

Franceville, Gabon

${ }^{4}$ Herbier National du Gabon, Institut de pharmacopée et de Médecine Traditionnelles B.P. 1156, Libreville, Gabon

DOI: $\underline{10.36347 / \text { sajp.2020.v09i01.001 }}$

| Received: 27.12.2019 | Accepted: 04.01.2020 | Published: 09.01.2020

*Corresponding author: Hilarion Mathouet

Abstract

Original Research Article

The present study was designated for the evaluation of the anti-inflammatory activity of four essential oils (Aucoumea klaineana Pierre, Canarium schweinfurthii Engl., Dacryodes buettneri HJ Lam, Dacryodes edulis (G. Don) HJ Lam) derived from medicinal plants from Gabon using the in vitro model. The anti-inflammatory activity of essential oils was determined using the method of denaturing the proteins of egg albumin. Essential oil of Aucoumea klaineana $\left(\mathrm{IC}_{50}=1.11 \pm 0.02 \mu \mathrm{g} / \mathrm{mL}\right)$ showed better thermal anti-denaturation efficacy of ovalbumin, followed by Dacryodes buettneri $\left(\mathrm{IC}_{50}=02.95 \pm 0.69 \mu \mathrm{g} / \mathrm{mL}\right)$ and Dacryodes edulis $\left(\mathrm{IC}_{50}=09.32 \pm 1.58 \mu \mathrm{g} / \mathrm{mL}\right)$. Canarium schweinfurthii essential oil $\left(\mathrm{IC}_{50}=13.51 \pm 1.34 \mu \mathrm{g} / \mathrm{mL}\right)$ exhibited weak activity compared to other essential oils, however, its inhibitory action is more effective than Diclofenac sodium $\left(\mathrm{IC}_{50}=22.39 \pm 1.04 \mu \mathrm{g} / \mathrm{mL}\right)$. This study supports the traditional use of these plants to treat certain disorders linked to inflammation.

Keywords: Anti-Inflammatory, essential oil, Aucoumea klaineana, Canarium schweinfurthii, Dacryodes buettneri, Dacryodes edulis.

Copyright @ 2020: This is an open-access article distributed under the terms of the Creative Commons Attribution license which permits unrestricted use, distribution, and reproduction in any medium for non-commercial use (NonCommercial, or CC-BY-NC) provided the original author and source are credited.

\section{INTRODUCTION}

Inflammation is the body's natural immune response to various aggressions which can be of physical, chemical, biological or infectious origin. Its current treatment is based on steroidal antiinflammatory drugs (glucocorticoids) and nonsteroidal. These molecules, although being effective, most often have undesirable effects which can hinder their longterm use [1].

Since antiquity, medicinal plants (essential oils or extracts) have played an important role in the prevention of human health. They continue to provide humanity with new remedies. It is therefore important to explore medicinal plants for their safety, quality, toxicity and effectiveness. Researchers are very interested in essential oils in order to combine them with existing molecules to increase their effectiveness [2].

Our interest was focused on the study of four essential oils (Aucoumea klaineana Pierre, Canarium schweinfurthii Engl., Dacryodes buettneri HJ Lam,
Dacryodes edulis (G. Don) HJ Lam) from medicinal plants widely used in traditional medicine in Gabon.

Aucoumea klaineana Pierre is a tree characteristic of the equatorial type forests, of secondary origin, its resin makes it possible to treat abscesses. The bark can be used as an antiseptic, astringent or antidiarrheal [3-5].

Canarium schweinfurthii Engl is a variety of large tree with compound leaves, with numerous predominant lateral veins. The resin is used in traditional medicine for the treatment of various diseases such as microbial wounds and infusions [6].

Dacryodes buettneri (Engl.) Guillaum, is a large tree, easily recognizable by its brilliant green leaves, with a reddish-white underside. Its resin is used to ripen abscesses. The thin platelets, which are removed from the bark, reduced to powder, are applied to burns (Walker and Sillans, 1961). 
Dacryodes edulis is a tree that can exceed 50 $\mathrm{m}$ in height. Its pulverized bark is applied to wounds, it is emetic and pesticidal $[3,7]$.

The objective of our study is to verify in vitro whether the use of essential oils as anti-inflammatories is justified.

\section{MATERIALS AND METHODS Plant Materials}

The resins of Aucoumea klaineana, Canarium schweinfurthii, Dacryodes buettneri and Dacryodes edulis were collected in December 2018 at the Sibang Arboretum (IPHAMETRA - Librevill - Gabon). Specimens were deposited at the National Herbarium of Gabon (IPHAMETRA). The essential oil was extracted from resin $(500 \mathrm{~g})$ by hydrodistillation in a clavengertype apparatus for $4 \mathrm{~h}$ and was dried, after decantation, over anhydrous sodium sulphate.

\section{Evaluation of the anti-denaturing effect of proteins}

In order to study the anti-inflammatory effect of essential oils, an in vitro evaluation test of the ability of these oils to prevent thermal denaturation of ovalbumin extracted from egg white by turbidimetry was used. In fact, heat causes the reversible change in the tertiary and even secondary conformation of proteins, which results in the reduction of their solubilities and the loss of their functions [8].

\section{Ovalbumin Extraction}

Ovalbumin was extracted from chicken egg white according to the method described by Datta et al., [9]. A fresh egg was broken and the yolk was separated from the white, the egg white was collected in a beaker put in an ice bath and mixed with $50 \mathrm{~mL}$ of phosphate buffer $(0.1 \mathrm{M}, \mathrm{PH}=6.6)$ then homogenized under magnetic stirring for $5 \mathrm{~min}$, then the homogenate obtained was centrifuged at $3000 \mathrm{rpm}\left(4^{\circ} \mathrm{C}\right)$ for $5 \mathrm{~min}$, the supernatant obtained was filtered through a strip of gauze to remove the precipitant. Finally, the filtrate obtained was partitioned into aliquots with a volume of 2 to $2.5 \mathrm{~mL}$ and then stored at $-20^{\circ} \mathrm{C}$.

\section{Measurement of the anti-denaturing activity of essential oils}

Protein denaturation methods have been used $[2,10]$ with slight modifications. Briefly, $0.1 \mathrm{~mL}$ of albumin from fresh chicken eggs was mixed with 1.9 $\mathrm{mL}$ of phosphate buffered saline (PBS, pH 6.4) and 1 $\mathrm{mL}$ of varying concentrations essential oils so that final concentrations range from 18.87 to $0.10 \mathrm{mg} / \mathrm{mL}$. A similar volume of distilled double water served as a negative control. Then, the mixtures were incubated at $37^{\circ} \mathrm{C}$ in an incubator (Ecocell, LSIS-B2V/EC55, Germany) for $20 \mathrm{~min}$ and then heated at $70^{\circ} \mathrm{C}$ for $5 \mathrm{~min}$. After cooling, the absorbances were measured at 660 $\mathrm{nm}$ on the spectrophotometer (Evolution 60S, USA). Diclofenac sodium in the final concentrations was used as a reference drug and similarly treated for the determination of absorbance.

$\%$ Inhibition $=\left[\left(\mathrm{Abs}_{\text {sample }}-\mathrm{Abs}_{\text {control }}\right) / \mathrm{Abs}_{\text {control }}\right]$ $\mathrm{x} 100, \mathrm{Abs}=$ absorbance. The concentration of the extract for a $50 \%$ inhibition $\left(\mathrm{IC}_{50}\right)$ was determined by the dose response curve.

\section{STATISTICAL ANALYSIS}

All data were measured average value of three replicates and standard error $( \pm)$. Results were subjected to Microsoft excel 2013 and kaleidagraph version 4.0.

\section{RESULTS}

To evaluate the anti-inflammatory activity in vitro of 4 essential oils (Aucoumea klaineana Pierre, Canarium schweinfurthii Engl., Dacryodes buettneri HJ Lam, Dacryodes edulis (G. Don) HJ Lam), we used the inhibition test of denaturing of ovalbumin extracted from chicken egg white. The $50 \%$ inhibitory concentrations of each essential oil are summarized in Table-1.

Table-1: Effect of four essential and diclofenac sodium against protein denaturation

\begin{tabular}{|l|l|l|l|}
\hline Plants / reference drug & $\mathbf{I C}_{\mathbf{5 0}}(\boldsymbol{\mu g} / \mathbf{m L})$ & Equation & $\mathbf{R}^{\mathbf{2}}$ \\
\hline Aucoumea klaineana & $1.11 \pm 0.02$ & $\mathrm{y}=64.09 \mathrm{x}+21.26$ & $\mathrm{R}^{2}=0.99$ \\
\hline Canarium schweinfurthii & $13.51 \pm 1.34$ & $\mathrm{y}=2.54 \mathrm{x}+15.66$ & $\mathrm{R}^{2}=0.98$ \\
\hline Dacryodes buettneri & $02.95 \pm 0.69$ & $\mathrm{y}=6.68 \mathrm{x}+30.23$ & $\mathrm{R}^{2}=0.99$ \\
\hline Dacryodes edulis & $09.32 \pm 1.58$ & $\mathrm{y}=3,68 \mathrm{x}+15.67$ & $\mathrm{R}^{2}=0.96$ \\
\hline Diclofenac sodium & $22.39 \pm 1.04$ & $\mathrm{y}=1.95 \mathrm{x}+6.33$ & $\mathrm{R}^{2}=0.96$ \\
\hline
\end{tabular}

From the $50 \%$ inhibition of ovalbumin denaturation, the concentrations of each essential oil were obtained. We find that all essential oils have the highest anti-inflammatory activities compared to Diclofenac sodium (reference anti-inflammatory).

Indeed, at the same concentrations of the different essential oils, Aucoumea klaineana $\left(\mathrm{IC}_{50}=\right.$ $1.11 \pm 0.02 \mu \mathrm{g} / \mathrm{mL}$ ) exhibited better anti-thermal denaturation efficacy of ovalbumin, followed by
Dacryodes buettneri $\left(\mathrm{IC}_{50}=02.95 \pm 0.69 \mu \mathrm{g} / \mathrm{mL}\right)$ and Dacryodes edulis $\left(\mathrm{IC}_{50}=09.32 \pm 1.58 \mu \mathrm{g} / \mathrm{mL}\right)$. Canarium schweinfurthii essential oil $\left(\mathrm{IC}_{50}=13.51 \pm\right.$ $1.34 \mu \mathrm{g} / \mathrm{mL}$ ) exhibited weak activity compared to other essential oils, however, its inhibitory action is more effective than Diclofenac sodium $\left(\mathrm{IC}_{50}=22.39 \pm\right.$ $1.04 \mu \mathrm{g} / \mathrm{mL}$ ). 
Mathouet H et al., Sch Acad J Pharm, Jan, 2020; 9(1): 1-4

\section{DISCUSSION}

Denaturation of proteins is a well-documented cause of inflammation. As part of the investigation into the mechanisms of anti-inflammation activity, the ability of essential oils from certain herbal plants to inhibit the denaturing of proteins was studied. Indeed, the essential oils tested (Aucoumea klaineana Pierre, Canarium schweinfurthii Engl., Dacryodes buettneri $\mathrm{H}$. J. Lam, Dacryodes edulis (G. Don) H. J. Lam) have an inhibitory effect on thermal denaturation, thus the stabilizing power of ovalbumin. The stabilization of proteins by these natural substances probably involves polyphenols and their metabolites which act as modulators of the signaling pathways of inflammation $[11,12]$.

The conformation of a protein is linked to the secondary and tertiary structure; it is carried out via low energy bonds (hydrogen, electrostatic, hydrophobic bonds and disulfide bridges) therefore fragile. Denaturation results from a modification of the quaternary, tertiary and secondary structures without fragmentation of the peptide chain under the effect of various chemical (acid, base, detergent) or physical (heat, PH) agents [13]. The increase in temperature generates a thermal agitation of the atoms of the molecule, therefore the denaturation of proteins goes through ephemeral structures which can lead to a total unfolding of the molecule but it is also considered that denaturation can result from an increase in structure beyond the native form. The expansion similar to a statistical ball structure increases the stability of the molecules. This denaturation modifies the properties of proteins [13].

The protein denaturation inhibition test is used in vitro to an anti-inflammatory activity evaluation test. The denaturation of a protein causes the induction of the inflammatory reaction by the production of autoantigens, important factors for developing chronic inflammation. This test is carried out in order to measure the inhibitory power of the thermal denaturation of protein by essential oils of Gabonese medicinal plants.

\section{CONCLUSION}

Nowadays, a large number of medicinal plants have very important biological properties certainly linked to their therapeutic properties. During this study, we evaluated the anti-inflammatory activity in vitro of four essential oils from medicinal plants in Gabon. The study shows that the in vitro anti-inflammatory activity of essential oils has proven protein stabilization activity against thermal denaturation with efficiency comparable to that of the non-steroidal antiinflammatory drug decofenac. These results remain preliminary and require further in-depth studies through anti-inflammatory activities in other systems in vitro (cellular and enzymatic) and in vivo (animal model) to better understand the molecular interactions of these compounds vis-à-vis of their targets.

\section{ACKNOWLEDGEMENTS}

The authors are very much thankful to the Shell Gabon for the financial support of materials in Laboratoire de Recherche en Biochimie (LAREBIO) USTM.

Disclosure: The authors declare that there are no competing interests. All the authors read and approved the final version.

\section{REFERENCES}

1. Etard JF, Ndiaye I, Thierry-Mieg M, Guèye NF, Gueye PM, Laniece I, Dieng AB, Diouf A, Laurent C, Mboup S, Sow PS. Mortality and causes of death in adults receiving highly active antiretroviral therapy in Senegal: a 7-year cohort study. Aids. 2006 May 12;20(8):1181-9.

2. Nemudzivhadi V, Masoko P. In vitro assessment of cytotoxicity, antioxidant, and anti-inflammatory activities of Ricinus communis (Euphorbiaceae) leaf extracts. Evidence-Based Complementary and Alternative Medicine. 2014;1-8.

3. Walker R, Sillans S. Plantes utiles du Gabon. Edition Lechevalier, Sepia, 1961:614.

4. White L, Abernethy K. Guide de la végétation de la réserve de la Lopé, Gabon. ECOFAC Gabon, Libreville. 1996:112.

5. Obame LC, Edou P, Koudou J, Kumulungui BS, Figueredo G, Chalchat JC, Bassolé IH, Traoré AS. Chemical composition, antioxidant and antimicrobial activities of Aucumea klaineana Pierre essential oil. African Journal of Pharmacy and Pharmacology, 2009;3(6):323-326.

6. Kerharo J. La Pharmacopée sénégalaise traditionnelle: plantes médicinales et toxiques. Editions Vigot Frères Paris: 1974;395-399.

7. Obame LC, Edou P, Bassolé IH, Koudou J, Agnaniet H, Eba F, Traore AS. Chemical composition, antioxidant and antimicrobial properties of the essential oil of Dacryodes edulis (G. Don) HJ Lam from Gabon. African Journal of Microbiology Research. 2008 Jun 30;2(6):148-52.

8. Adrach verma M, Ajay Kumar P, Kavitha D, Aurag KB. Anti denaturation and antioxidant activity of Annon cherimola in vitro. International Journal of Pharma and Bio Science. 2011;2(2):1-6.

9. Datta D, Bhattacharjee $S$, Nath A, Das R, Bhattacharjee C, Datta S. Separation of ovalbumin from chicken egg white using two-stage ultrafiltration technique. Separation and Purification Technology. 2009 Apr 20;66(2):35361.

10. Sima-Obiang C, Ngoua-Meye-Misso RL, NdongAtome GR, Ondo JP, Obame-Engonga LC, NsiEmvo E. Phytochemical screening, phenolic compounds content, antioxidant, antiinflammatory, and antimicrobial properties of 
Pachylobus balsamifera Guillaum from Gabon. Phytothérapie. 2018 Dec 1;16(S1):S65-73.

11. Chandra S, Chatterjee P, Dey P, Bhattacharya S. Evaluation of in vitro anti-inflammatory activity of coffee against the denaturation of protein. Asian Pacific Journal of Tropical Biomedicine. 2012 Jan 1;2(1):S178-80.

12. Ngoua-Meye-Misso RL, Sima-Obiang C, Ndong JD, Ondo JP, Ovono Abessolo F, Obame-Engonga LC. Phytochemical screening, antioxidant, anti- inflammatory and antiangiogenic activities of Lophira procera A. Chev.(Ochnaceae) medicinal plant from Gabon. Egyptian Journal of Basic and Applied Sciences. 2018 Mar 1;5(1):80-86.

13. Karthik K, Bharath RP, Venu Priya R, Sunil Kumar K, Ranjith Singh B. Evaluation of antiinflammatory activity of canthium parviflorum by in-vitro method. Indian Journal of Research in Pharmacy and Biotechnology, 2013;2320-3471. 